\title{
Growth, allocation and leaf gas exchanges of hybrid poplar plants in their establishment phase on previously forested sites: effect of different vegetation management techniques
}

\author{
Lluis COLL $^{\mathrm{a}, \mathrm{b} *}$, Christian MESSIER ${ }^{\mathrm{a}}$, Sylvain DELAGRANGE ${ }^{\mathrm{a}, \mathrm{c}}$, Frank BERNINGER $^{\mathrm{a}}$ \\ ${ }^{a}$ Centre d'Étude de la Forêt (CEF), Université du Québec à Montréal, C.P. 8888, Montréal, Qc, H3C 3P8, Canada \\ ${ }^{\mathrm{b}}$ Present address: Centre Tecnològic Forestal de Catalunya (CTFC), Pujada del seminari s/n, 25280, Solsona, Spain \\ c Present address: Institut Québécois d'Aménagement de la Forêt Feuillue (IQAFF), 58 rue Principale, Ripon, Qc, J0V 1V0, Canada
}

(Received 3 July 2006; accepted 13 October 2006)

\begin{abstract}
The effect of different vegetation control methods (mowing and cultivation between plantation rows, herbicide application and cover plant sowing) on hybrid poplar (P. maximowiczii $\times$ balsamifera) growth, biomass allocation and leaf carbon assimilation was investigated in two plantations (1- and 2-year-old) established in previously forested sites of south-eastern Québec. Any vegetation control treatment applied the same year in which the plantation was established did not have an effect on hybrid poplar aboveground growth. However significant differences among treatments were observed belowground, where the removal of the competing vegetation at the tree base increased the fine root:leaf biomass ratio of plants, thus probably facilitating their establishment. In contrast, 2-year-old plants grew better when treated with herbicides, but no positive effect of the mechanical treatments was detected. In both sites, trees growing on herbicide-treated plots showed considerably higher leaf carbon assimilation and leaf $\mathrm{N}$ concentration which were both strongly correlated. We conclude that a strong vegetation competition for nutrients takes effect on hybrid poplar plantations on previously forested sites since there was no water shortage for any treatment during the study period.
\end{abstract}

competition / hybrid poplar / biomass allocation / photosynthesis / vegetation management

\begin{abstract}
Résumé - Effet de différentes méthodes de gestion de la végétation compétitrice dans la croissance, l'allocation de biomasse et les échanges gazeux du peuplier hybride pendant sa phase d'établissement dans des milieux anciennement boisés. L'effet de différentes méthodes de contrôle de la végétation compétitrice (fauchage et hersage mécanisé, herbicide, semence de plantes de couverture) a été étudié sur la croissance, l'allocation de biomasse et l'assimilation de carbone du peuplier hybride $($. maximowiczii $\times$ balsamifera $)$. Les mesures ont été effectuées sur des individus provenant de deux plantations localisées sur des anciennes terres boisés dans le sud-est du Québec et établies la même année ou l'année précédant l'étude. Lorsqu'elles sont appliquées la même année que l'installation de la plantation, aucune des méthodes de contrôle de la végétation n'a eu d'effets sur la croissance aérienne des individus. Cependant, l'élimination de la végétation autour de la base des peupliers a affecté la partie racinaire des individus en augmentant le ratio de biomasse des racines fines:biomasse foliaire ce qui a probablement favorisé leur installation. Par contre, dans la plantation établie l'année antérieure, une plus forte croissance en diamètre et en hauteur a été observée chez les peupliers traités avec des herbicides alors que les traitements mécaniques n'ont encore une fois pas eu d'effet sur les individus. Dans les deux plantations, les arbres traités avec des herbicides présentaient une meilleure capacité d'assimilation de carbone et une meilleure teneure en $\mathrm{N}$ foliaire. Étant donné qu'aucune limitation hydrique n'a été mise en évidence pendant la période de l'étude, nous concluons qu'une forte compétition pour les éléments nutritifs existe dans les jeunes plantations de peupliers hybrides établies sur des anciennes terres boisées.
\end{abstract}

compétition / peuplier hybride / allocation de biomasse / photosynthèse / gestion de la végétation forestière

\section{INTRODUCTION}

Plantations of fast-growing trees such as hybrid poplars, which present considerably higher wood yields than most natural forests, are more and more considered as an important component of forest management strategies to meet both production and forest conservation targets [37]. For example, in southern Québec hundreds of hectares of hybrid poplar (Populus ssp.) are planted each year by forest industries on previously logged forest sites. On these sites, current vegetation management practices include mechanical site preparation (disking) the year before planting and inter-row mechanical mowing from the second growing season onward.
Poplar trees are often reported as being very sensitive to belowground competition $[5,28]$ and thus effective weed control is critical for the success of their establishment and growth $[6,46]$. Even though mechanical mowing with forest tractors is broadly used by the forest companies in Québec (particularly since the ban on the use of herbicides in public forests which took effect in 2001), its real efficacy in controlling vegetation competition and promoting short-rotation tree establishment and growth is unknown. In this study mechanical mowing was evaluated by comparing its effect on ground vegetation growth and tree development with a set of treatments (soil cultivation, the use of a plant cover, "local" herbicide application, full-plot herbicide application and a control). Although the advantages and inconvenients of the different techniques are well known and have 
been reviewed recently [3,23], studies testing such a set of treatments in natural conditions in regions not limited by water shortage are not common. In addition, in Canada there have been few studies focusing on weed management in hybrid poplar established on forested sites [47], because most of the existing research has been conducted in plantations on former agricultural land.

Much previous work on the effect of ground vegetation management on plantation establishment and growth has focused on tree survival as well as on the response of the aerial part of the tree (e.g. $[9,26,30,40])$. However, during the establishment phase a good and rapid development of the plant root system is critical for the success of these plantations through reduction of transplant shock and associated plant mortality or severe stem dieback [43]. In the case of hybrid poplar plantations in Québec, transplanting shock problems could be even exacerbated by the common use of large size planting stock (with the aim of reducing deer browsing damage) which presents a low root to shoot ratio [51]. Several studies have reported that plants respond to competition for belowground resources by increasing biomass allocation to roots $[8,53]$. However various authors pointed out the importance of considering ontogenetic development when studying shifts in biomass partitioning [16, 25, 31, 35] and Cahill [7] recently reported a lack of an allocation response to belowground competition in 10 grasses. Instead he related variation in root's allocation patterns under different competition regimes to differences in plant size (i.e. plants were bigger when developing under favourable growth conditions without competitors). Similar conclusions were found by Coleman et al. [12] in an experiment conducted in Populus deltoides stands submitted to different fertilization and irrigation regimes. The role played by resource availability and plant size in biomass allocation to roots is thus unclear and needs further study [15]. In this study the biomass allocation and physiological response of one- (1YS) and two- year-old (2YS) hybrid poplar plantations to different vegetation control methods and belowground competition is evaluated. We particularly focused on competition for nitrogen which is the element that most commonly limits growth in well watered soils $[30,44]$.

Specifically, the following questions were addressed: (i) What is the effectiveness of the present mechanical mowing treatment in controlling vegetation in previously forested sites? (ii) How recently established hybrid poplar plants respond to belowground competition in terms of both growth and photosynthetic activity? and (iii) What is the role played by plant size in biomass allocation shifts in plants under different competition regimes?

\section{MATERIALS AND METHODS}

\subsection{Study site}

The research was conducted on hybrid poplar (Populus maximowiczii $\times$ P. balsamifera, clone 915311$)$ plantations established on previously forested sites near La Patrie $\left(45^{\circ} 20^{\prime} \mathrm{N}, 71^{\circ} 34^{\prime} \mathrm{W}\right)$ in the south-eastern part of Québec. Prior to harvesting, these sites were dominated by maples (Acer saccharum Marsh. and Acer rubrum L.) and to a lower extent by yellow birch (Betula alleghaniensis Britt.) and American beech (Fagus grandifolia Ehrenb.). These forests were harvested in 1995 following clearcut strips of about $80 \mathrm{~m}$ wide. Mean annual precipitation in the area is $1100 \mathrm{~mm}$ and mean annual temperature is about $4.5^{\circ} \mathrm{C}$. During the vegetative growing season (MayOctober) precipitation is abundant and well distributed (Fig. 1) with a climatic normal of $652 \mathrm{~mm}$ (at Sherbrooke airport, near the study site, Environment Canada [20]). Since such a precipitation regime can induce waterlogging problems to plants on the poorly drained sites, most hybrid poplar plantations are established in moderately slopped areas.

Our study plantations were established in a soil which is primarily a moderately well drained loam of $\mathrm{pH} 4-5$, having a northern aspect with slopes of $8-15 \%$. Herbaceous vegetation is dominated by a mixture of grasses (mainly Poa spp., Carex spp.) covering about $65 \%$ of soil and forbs (mainly Solidago canadensis L.) covering about $55 \%$ of soil. Shrubs (mainly Rubus idaeus L.) were sparse and covered around $5 \%$ of soil. Vegetation composition was fairly similar among stands.

\subsection{Experimental design}

Six hybrid poplar stands (block units in our experimental research) growing on former clearcut strips were selected. Three of the stands were planted in 2003, the year before the study (2-year-site, 2YS), and the other three at the beginning of May 2004 (1-year-site, 1YS). All the sites were cleared of woody debris and the brush was cut and the soil disked (by a modified forestry disk-harrow) a year before planting.

In both sites, tall bare-root plants $(1-2 \mathrm{~m})$ were used to minimize deer damage and were planted with a $3 \times 3 \mathrm{~m}$ spacing. In the beginning of June 2004, six different weed-control treatments were set up in each stand. The treatments, applied on plots of $18 \times 18 \mathrm{~m}$ (36 trees), were: (1) mechanical mowing between plantation rows using a tractor with a 4 blade Brown Tree Cutter $(M)$; (2) mechanical shallow cultivation (10 cm-deep) between plantation rows using a tractor with a 16 disk Schmeiser's (RTH-16N model) (C); (3) "total" vegetation removal using herbicides (Glyphosate $356 \mathrm{mg} \mathrm{L}^{-1}$ active principle, $2 \%$ concentration) manually sprayed $(H)$; (4) "local" herbicide application $(0.5-\mathrm{m}$ radius around the tree base) $(L H) ;(5)$ the use of a sowed cover plant mixture $(C P)$ and (6) no vegetation treatment (control) $(V)$. The sowed mixture was composed of rye (Secale cereale, $30 \mathrm{~kg} \mathrm{ha}^{-1}$ ), oat (Avena sativa, $30 \mathrm{~kg} \mathrm{ha}^{-1}$ ), mustard (Sinapis alba, $8 \mathrm{~kg} \mathrm{ha}^{-1}$ ), buckwheat (Fagopyrum ssp., $8 \mathrm{~kg} \mathrm{ha}^{-1}$ ) and phacelia (Phacelia ssp., $2 \mathrm{~kg} \mathrm{ha}^{-1}$ ). The composition was established from tests recently carried out in France [38]. The soil was mechanically prepared (inter-row double-cultivation) before sowing the cover plant mixture.

Overall, the experiment used a randomized complete block design for each year of plantation (2YS and 1YS), with three blocks and six treatments. Each treatment was applied once in each block. To avoid edge effects, the measurements were carried out on the sixteen inner trees of each treatment plot.

\subsection{Hybrid poplar growth and development}

Total stem height, diameter and terminal shoot elongation were measured in June and September 2004 in sixteen trees per treatment 


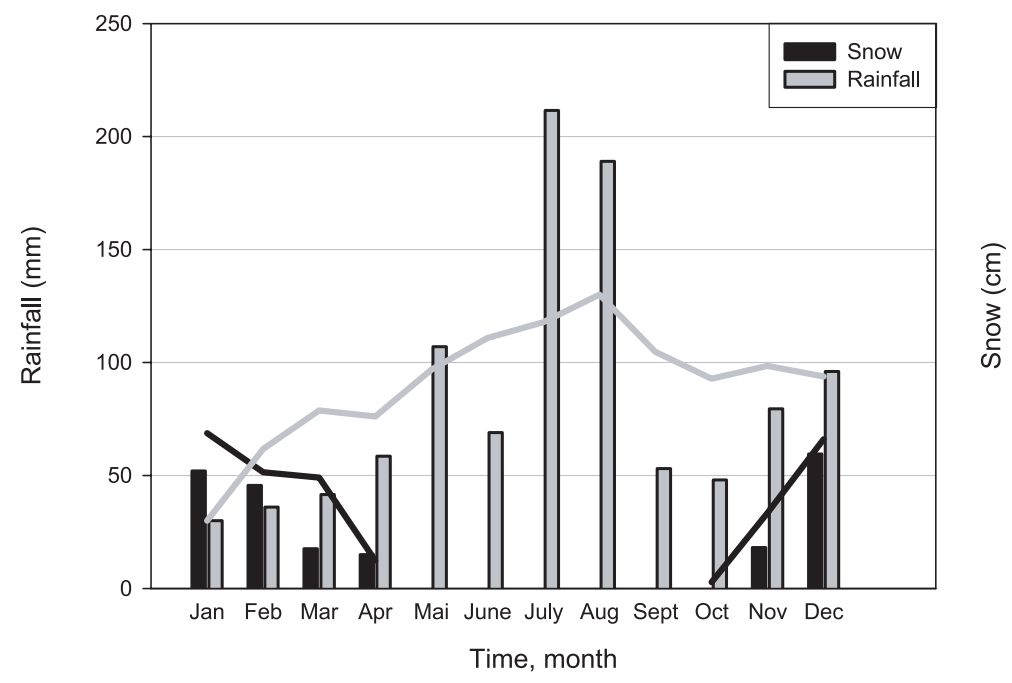

Figure 1. Absolute monthly precipitation $(\mathrm{mm})$ and snow $(\mathrm{cm})$ during the year of study are represented in columns. Solid lines represent the monthly average values in the study site for the 1971-2000 period. Snow is represented in black and rainfall in grey colour.

thus totalling 288 trees per plantation year. In the beginning of the experiment trees from the 2YS plantation averaged $9 \mathrm{~mm}$ diameter and $171 \mathrm{~cm}$ height and those from 1YS, $9.2 \mathrm{~mm}$ of diameter and $129 \mathrm{~cm}$ height. Diameter was measured using a digital calliper at a permanently marked point at breast height (2YS) and at $50 \mathrm{~cm}$ above ground (1YS). At the end of the growing season, four trees per block and treatment (totalling twelve trees per treatment and plantation year) were totally harvested by hand for biomass estimation. As this was very time-consuming, we excavated trees from the $L H$ (representative of the "herbicide group" and from treatments which removed vegetation at tree base), the $C P$ (representative of the "mechanical" treatments which removed vegetation inter-row) and the control $(V)$ treatments. Trees were carefully harvested by hand to prevent breaking roots and then cool-stored at $5{ }^{\circ} \mathrm{C}$. Tree biomass was divided into six parts: leaves, branches, stems, taproots, coarse-roots (diameter $>$ $2 \mathrm{~mm}$ ) and fine roots (diameter $<2 \mathrm{~mm}$ ); then oven-dried at $70^{\circ} \mathrm{C}$ for $96 \mathrm{~h}$ and weighed.

\subsection{Ground vegetation biomass}

Weed aboveground biomass was measured on August 4, two months after the different vegetation control treatments were applied. In each experimental treatment, a $50 \mathrm{~cm} \times 50 \mathrm{~cm}$ square was randomly placed at five different positions in the middle of the tree rows and at the base of five different trees randomly selected from the unmeasured trees. The vegetation encountered inside each square was clipped and placed in bags. Each sample was oven-dried at $70{ }^{\circ} \mathrm{C}$ for 4 days and weighed.

\subsection{Belowground resources availability}

Volumetric soil water content (SWC, \%) was measured once (July 20) after 7 days without rain with a time domain reflectometer (TDR) probe (Trime P3, IMKO ${ }^{\mathrm{TM}}$, Ettlingen, Germany). In each treatment, measurements were conducted in the upper horizon $(12 \mathrm{~cm}$ depth) in 10 locations between rows and at the base of 10 trees. Since frequent rainfall events occurs from May to October (about $670 \mathrm{~mm}$, Fig. 1), SWC monitoring was reduced to one date (in the middle of the growing season) that we consider as representative of the mean soil water conditions of the site during the measurement period.

On August 20, eight pairs (anion and cation) of PRS-probes (Western Ag Innovations, Inc., Saskatoon, Canada) were installed in each treatment at the base of eight trees to estimate the nitrogen available for plants in the soil $\left(\mathrm{NO}_{3}^{-}\right.$and $\mathrm{NH}_{4}^{+}$were combined together for total $\mathrm{N}$ calculation). The PRS probes use a charged membrane (approx. $17.5 \mathrm{~cm}^{2}$ ) which absorbs nutrients from the soil similar to how plant roots absorb nutrients (see [27] for details). The probes measure the amount of nutrients absorbed by the membrane during the period underground $\left(\mu \mathrm{g} \mathrm{N} / 10 \mathrm{~cm}^{-2}\right.$ ). In this experiment, the probes were left in the soil four weeks then removed and cool stored. The eight probes from the same treatment were combined and analysed in groups of four, which resulted in two values per experimental treatment.

\subsection{Leaf gas exchange and leaf nitrogen content}

Leaf gas exchange was measured during the third week of August in four trees per treatment and block with a portable leaf chamber system (LI-6400, Li-Cor, Lincoln, NE, USA). Measurements were conducted between 10:00 and 14:00 h in sunny days. In each tree, measurements of maximum steady-state net photosynthetic rates at light saturation $\left(A_{\max }\right)$ and leaf intercellular $\mathrm{CO}_{2}$ concentration $\left(C_{i}\right)$ were carried out on one mature leaf taken from the upper part of the canopy. For $A_{\max }$ and $C_{i}$ determination, light and $\mathrm{CO}_{2}\left(C_{a}\right)$ in the chamber were maintained at $1500 \mu \mathrm{mol} \mathrm{m} \mathrm{m}^{-2} \mathrm{~s}^{-1}$ PAR and $360 \mathrm{ppm}$ respectively, while leaf temperature was set at $25{ }^{\circ} \mathrm{C}$. The relative chlorophyll content of the same leaves was estimated with a chlorophyll meter (SPAD-502 ${ }^{\mathrm{TM}}$, Minolta, Osaka, Japan) as the average of ten readings. The leaves were then collected, scanned and their areas determined using the Macfolia software package (Régent instruments, Québec, Canada). Measured leaves were oven-dried and their $\mathrm{N}$ content determined following Kjeldahl digestion (Kjeltec Tecator 1030). 
Table I. Weed biomass (at tree base and inter-row) and belowground resource availability for the different experimental treatments. For each treatment each value is the mean and standard error of three different blocks. For each year, different letters indicate significant differences between treatments $(P<0.05)$. Abbreviations: $V$ (control, non-vegetation management), $H$ (whole-plot herbicide application), $L H$ (local herbicide application around tree base), $C P$ (Double-cultivation of soil and cover plant mixture sowing), $M$ (mechanical mowing with forest tractor), $C$ (single mechanical cultivation with forest tractor). The same treatment abbreviations are used in all figures.

\begin{tabular}{|c|c|c|c|c|c|c|c|c|c|c|c|c|}
\hline & \multicolumn{6}{|c|}{$2 \mathrm{YS}$} & \multicolumn{5}{|c|}{$1 Y S$} & \multirow[b]{2}{*}{$C$} \\
\hline & V & $H$ & $L H$ & $C P$ & $M$ & $C$ & V & $H$ & $L H$ & $C P$ & $M$ & \\
\hline \multirow{3}{*}{$\begin{array}{l}\text { Weed biomass, } \\
\text { t ha }^{-1} \text { (tree base) }\end{array}$} & 2.62 & 0.33 & 0.13 & 2.9 & 2.74 & 2.92 & 2.04 & 0.38 & 0.13 & 2.17 & 2.65 & 2.31 \\
\hline & $( \pm 0.22)$ & $( \pm 0.05)$ & $( \pm 0.04)$ & $( \pm 0.13)$ & $( \pm 0.32)$ & $( \pm 0.28)$ & $( \pm 0.20)$ & $( \pm 0.05)$ & $( \pm 0.02)$ & $( \pm 0.06)$ & $( \pm 0.25)$ & $( \pm 0.30)$ \\
\hline & $\mathrm{a}$ & $\mathrm{b}$ & $\mathrm{b}$ & a & $\mathrm{a}$ & $\mathrm{a}$ & $\mathrm{a}$ & $\mathrm{b}$ & $\mathrm{b}$ & $\mathrm{a}$ & $\mathrm{a}$ & $\mathrm{a}$ \\
\hline \multirow{3}{*}{$\begin{array}{l}\text { Weed biomass, } \\
\text { t ha }^{-1} \text { (inter-row) }\end{array}$} & 3.29 & 0.13 & 2.85 & 1.06 & 2.46 & 1.94 & 2.53 & 0.23 & 2.00 & 0.88 & 2.38 & 1.00 \\
\hline & $( \pm 0.36)$ & $( \pm 0.02)$ & $( \pm 0.25)$ & $( \pm 0.08)$ & $( \pm 0.25)$ & $( \pm 0.27)$ & $( \pm 0.17)$ & $( \pm 0.047)$ & $( \pm 0.19)$ & $( \pm 0.07)$ & $( \pm 0.27)$ & $( \pm 0.24)$ \\
\hline & $\mathrm{a}$ & d & $a b$ & $\mathrm{c}$ & $a b$ & $\mathrm{~b}$ & $\mathrm{a}$ & $\mathrm{c}$ & $\mathrm{a}$ & $\mathrm{b}$ & $\mathrm{a}$ & $\mathrm{b}$ \\
\hline \multirow{3}{*}{$\begin{array}{l}\text { Volumetric soil water } \\
\text { content, \% (TDR) }\end{array}$} & 37.8 & 37.7 & 37.16 & 32.5 & 32.26 & 37.51 & 41.7 & 44.1 & 34.49 & 42.6 & 41.97 & 35.33 \\
\hline & $( \pm 1.17)$ & $( \pm 1.15)$ & $( \pm 1.27)$ & $( \pm 1.28)$ & $( \pm 1.07)$ & $( \pm 1.51)$ & $( \pm 1.29)$ & $( \pm 1.22)$ & $( \pm 1.06)$ & $( \pm 1.21)$ & $( \pm 1.32)$ & $( \pm 1.12)$ \\
\hline & $\mathrm{a}$ & $\mathrm{a}$ & $\mathrm{a}$ & $\mathrm{b}$ & $\mathrm{b}$ & $\mathrm{a}$ & $\mathrm{a}$ & $\mathrm{a}$ & $\mathrm{b}$ & $\mathrm{a}$ & $\mathrm{a}$ & $\mathrm{b}$ \\
\hline \multirow{3}{*}{$\begin{array}{l}\text { Soil N content } \\
\text { (PRS-probes) }\end{array}$} & 12.97 & 47.47 & 31.07 & 17.63 & 14.67 & 17.63 & 17.33 & 23.73 & 35.93 & 19.73 & 18.18 & 22.93 \\
\hline & $( \pm 1.36)$ & $( \pm 17.31)$ & $( \pm 8.77)$ & $( \pm 2.75)$ & $( \pm 2.46)$ & $( \pm 1.58)$ & $( \pm 2.20)$ & $( \pm 4.30)$ & $( \pm 7.70)$ & $( \pm 2.72)$ & $( \pm 2.95)$ & $( \pm 4.52)$ \\
\hline & $\mathrm{a}$ & $\mathrm{c}$ & $\mathrm{bc}$ & $a b$ & $\mathrm{a}$ & $a b$ & $\mathrm{a}$ & $\mathrm{a}$ & $\mathrm{a}$ & $\mathrm{a}$ & $\mathrm{a}$ & $\mathrm{a}$ \\
\hline
\end{tabular}

\subsection{Data analysis}

The data were analysed using an analysis of variance (ANOVA) technique for a randomized complete block design. When treatment differences occurred, a Bonferroni corrected $t$-test was used to compare treatments means. Trees showing strong signs of being unhealthy due to green-flies or cochineal's infestation, or severe stem injuries from the treatment applications and thus not related to the competing vegetation were not included in the analysis. That represented among 3 to 10 trees per treatment and plantation year.

Leaf, root, stem, and branch weight fraction (LWF, RWF, SWR, BWR) were calculated as biomass allocated in each compartment ( $\mathrm{g}$ ) divided by total plant biomass $(\mathrm{g})$. The fine root:leaf biomass ratio (FRLR) was calculated as fine root biomass divided by leaf biomass.

To take into account both plant-development and treatment effects on biomass partitioning, ANCOVA analyses were computed using tree height as a covariate and the different plant biomass fractions as dependent variable. Data was transformed when residuals were heteroscedastic or not normal. All data analyses were made using Statgraphics Plus 5.1 software (Statistical Graphics, Rockville, MD).

\section{RESULTS}

\subsection{Competing vegetation and belowground resources}

The mixture of seeds sowed in the $C P$ treatment did not establish well and their presence was very sparse during the month after sowing. Hence hereafter the $C P$ treatment should be considered in this study as an "intensive" cultivation treatment (as the soil was cultivated twice before sowing the mixture) rather than as real plant cover treatment.

In both plantations (1YS and 2YS) the mechanical treatments $(C P, M, C)$ did not have any effect on the competing vegetation surrounding the base of the trees (Tab. I). Inter-row weed biomass was significantly reduced by about $40 \%$ and $60 \%$ by both soil cultivation treatments ( $C$ and $C P$, respectively) but, two month after the application of the treatments, no difference in inter-row weed biomass was found between the mowed plots $(M)$ and the control ( $V)$ (Tab. I). The application of herbicides in the beginning of the growing season $(H$ and $L H$ ) critically reduced weed biomass around tree base during the whole growing season (Tab. I). Abundant precipitation events occurred in this area during the growing season (Fig. 1) and no sign of water stress in plants or in the vegetation were observed throughout the summer. The TDR measurement we performed in July revealed high soil water content levels for all the treatments with values ranging between $30 \%$ and $45 \%$ even 7 days after precipitations (Tab. I). No differences on SWC were obtained among the measurements made at the tree base and those made between the planting rows.

PRS-probes analysis indicated that the $H$ and $L H$ treatments increased the availability of $\mathrm{N}$ in the soil in both plantation years (Tab. I), although differences were only significant in the 2YS. $M$ and $V$ treatments presented the lower soil $\mathrm{N}$ values in both sites.

\subsection{Hybrid poplar growth}

Hybrid poplar diameter and height increments in both $H$ and $L H$ were respectively about 4 and 2.5 times those in the other treatments (Fig. 2a) in the plantation established in 2003 (2YS). No significant difference in hybrid poplar growth existed between the other vegetation control treatments $(M, C$, $C P$ ) and the control $(V)$. In the plantations established in 2004 (1YS), no differences were evident in diameter and height growth between the different vegetation control treatments (Fig. 2b). 


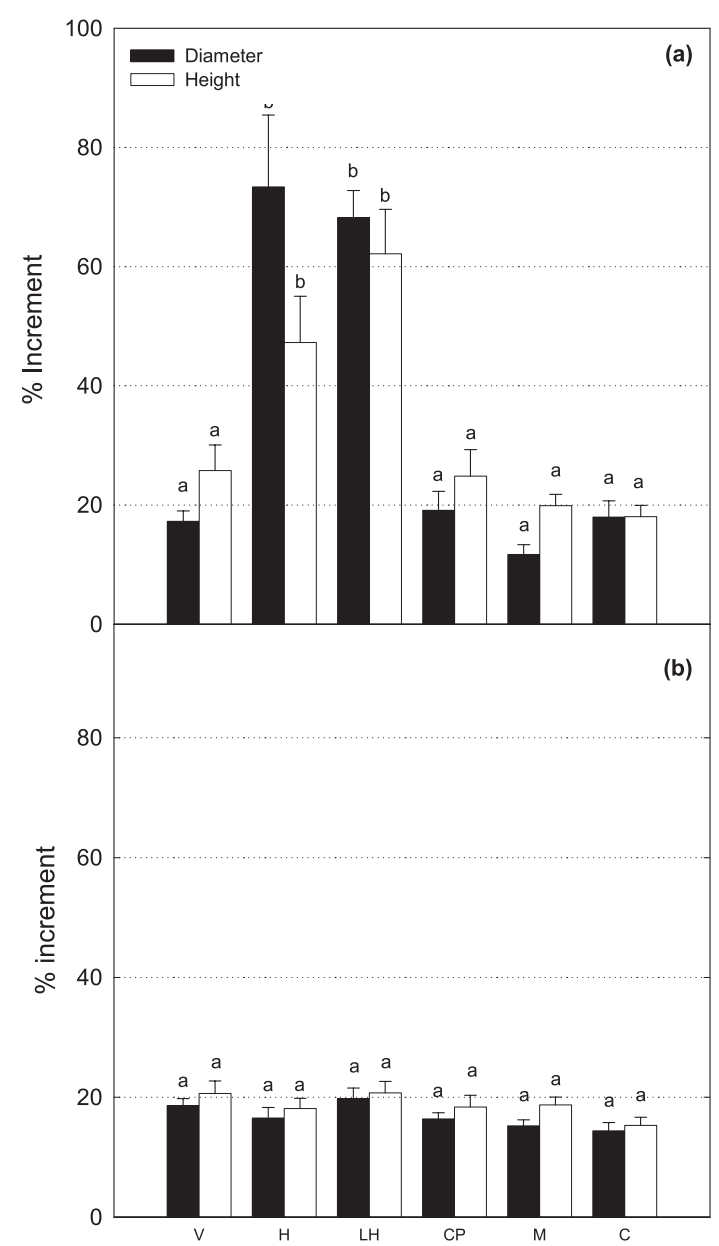

Figure 2. Hybrid poplar diameter (filled bars) and height (open bars) increment $(\%$, mean \pm standard error) for (a) the plantations established two years ago (2YS, $n=38$ to 45 plants per treatment) and (b) recent established plantations (1YS, $n=41$ to 47 plants per treatment). Significant differences $(P<0.05)$ between treatments are indicated by different letters (Bonferroni $t$-test, $95 \%$ confidence interval).

\subsection{Photosynthesis and leaf characteristics}

In both plantations, trees growing in the $H$ and $L H$ treatments showed considerably higher maximum photosynthetic rates (ranging between 18.5 and $23 \mu \mathrm{mol} \mathrm{m}{ }^{-2} \mathrm{~s}^{-1}$ ) compared to trees growing in the other treatments (Fig. 3a). No significant differences in $A_{\max }$ occurred between the control $(V)$ and the various mechanical treatments. Leaf nitrogen concentration and relative chlorophyll content estimated with SPAD followed the same pattern as $A_{\max }$ (Figs. 3b, 3c) and were about 25\% higher in the $H$ and $L H$ treatments than in other treatments. The $C_{i} / C_{a}$ ratio ranged from 0.63 ( $L H$ and $H$ treatment for the 1- and 2YS) to 0.74 and 0.76 ( $V$ and $C$ for the 1 - and 2YS respectively) and was significantly lower in the herbicide-treated plants compared to the plants growing in the other treatments. Leaf-mass area was lower in trees growing in the $H$ and $L H$ treatments (only significant in 2YS) (data not shown), but leaf nitrogen content on an area-basis $\left(N_{a}\right)$ was still significantly higher in the $L H$ and $H$ treatments (Fig. 3d). A tight logarithmic relationship was found between $A_{\max }$ and $N_{a}$ values that included all treatments for both $1 \mathrm{YS}$ and $2 \mathrm{YS}$ with $R^{2}=0.81$ and 0.77 , respectively (Fig. 4).

\subsection{Hybrid poplar biomass partitioning}

Variations in biomass partitioning were mainly associated to tree height (Tab. II). In the 2YS, plants decreased their allocation to roots and rapidly increase branching when increasing size (Fig. 5). A near-significant effect of treatment $(P<0.1)$ was nonetheless detected in the leaf and branch weight fraction, plants being treated with herbicides presenting higher allocation to leaf and branches than those from the $C P$ and $V$ treatments.

In the 1YS, plant height explained most variation on the aboveground compartments (BWR and SWR) of plants (Tab. II, Fig. 6). However the ANCOVA analysis detected differences among treatments in the FRLR $(P=0.059)$ with trees being locally treated with herbicides presenting considerably higher FRLR values than plants from the other treatments (Fig. 7).

\section{DISCUSSION}

\subsection{Comparison of weed control techniques}

The different vegetation control treatments practiced in this study differed in their success in terms of controlling the weeds. Two months after the application of the treatments, the presence of competing vegetation in the mechanical mowed plots was not different from the control due to rapid vegetation regrowth. The inefficiency of mechanical mowing as a weed control method when herbs dominate the ground vegetation has been pointed out in other studies [17, 33]. Boulet-Gercourt [4] even reported this technique to favour the presence of most competitive grasses species in some cases and thus increase herbaceous competition. However, mechanical mowing seems appropriate for controlling woody competitors (i.e. shrubs, understorey hardwoods) [3] and thus its value as a weed control method seems highly dependent on the competing vegetation type [38]. Single and double shallow soil cultivation $(C$ and $C P)$ significantly reduced inter-row weed biomass, but none of the mechanical treatments did reduce weed presence in the vicinity of the tree base (Tab. I). This is due to the fact that in order to minimize tree damage with the machinery, the area at the base of the tree is often left uncultivated. Our study clearly reflects (through the LH treatment) that competition in recent established plantations mainly occurred around the base of the tree $[22,41,46,55]$. Hence, the current mechanical vegetation controls applied in these sites the first years after planting do not seem appropriate and need to be reconsidered. In our plots, herbicide application $(L H, H)$ was the most efficient technique in mitigating the effects of weed competition on hybrid poplar growth and photosynthetic 


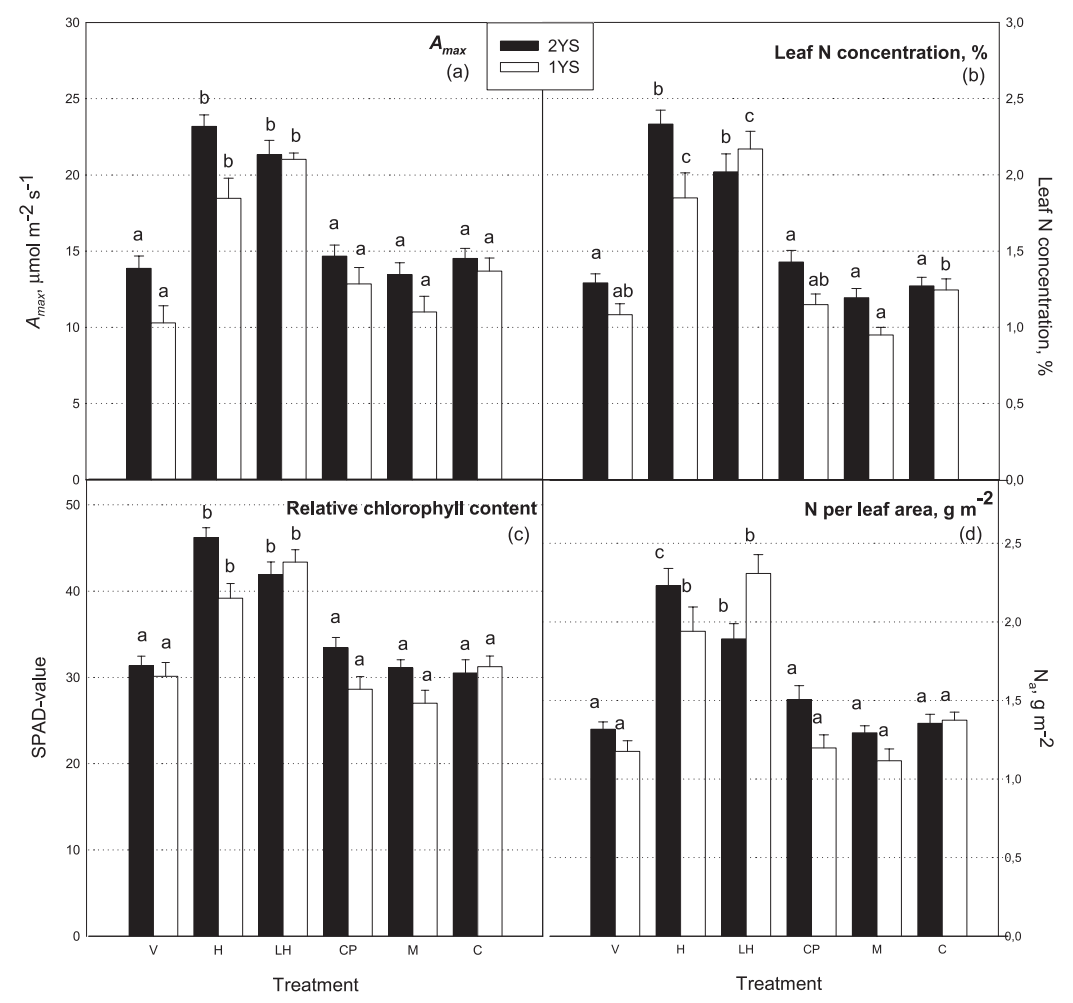

Figure 3. Mean and standard error values $(n=12)$ of hybrid poplar maximum rate of photosynthesis $\left(A_{\max }\right)$, leaf $\mathrm{N}$ concentration, leaf chlorophyll content (estimated with the SPAD meter) and $\mathrm{N}$ per leaf area $\left(N_{a}\right)$ for the different experimental treatments and plantation years (2YS filled bars, 1YS open bars). Significant differences $(P<0.05)$ between treatments are indicated by different letters $($ Bonferroni $t$-test, $95 \%$ confidence interval).

capacities. However their use meets at present widespread opposition from the public [24] and thus there is a need of exploring and testing feasible alternatives to them [34]. The use of a plant cover mixture composed by "favourable herbs" (i.e. less competitive for belowground resources) has been tested with success by some European research teams $[23,42,52]$ as an affordable "ecological" alternative to herbicides. Unfortunately in our study we could not assess the efficacy of this technique in controlling weed development because the cover plant mixture we sowed did not grow well. The low establishment rate may have been due to a poor selection of herb species or to the rapid growth of the native vegetation, which was not totally removed during site preparation. We think that further research is required to define adequate protocols to promote efficient plant cover establishment to various sites. Finally we did not test the use of organic or synthetic mulches to control weeds and favour plant establishment although they have been proved as effective as herbicides in controlling vegetation competition in many systems $[1,36,39]$. At present, the high economic cost associated to their use still restricts their application to specific situations [26].

\subsection{Hybrid poplar growth and leaf carbon assimilation}

The results of our study agree with those reported in other experiences that point out the high sensitivity of poplar species to belowground competition [28, 46]. In the $2 \mathrm{YS}$ plantation, the growth of hybrid poplar was dramatically increased when total $(H)$ or local $(L H)$ removal of weeds was practiced (Fig. 1a), and confirmed the importance of an efficient weed management for the success of short-rotation poplar plantations $[6,50]$. Assessing the duration of the vegetation control treatment was not the objective of this study but Hansen et al. [29] recommended controlling vegetation the first 3-4 years after plantation until plant will be shading out the weeds. In addition, Stanturf et al. [44] pointed out the need of managing weed competition from the first growing season. In this study, we did not detect an effect of any of the weed treatments on plant diameter or height growth in recent established plantations (1YS), but in both sites $L H$ and $H$ plants presented considerably higher maximum photosynthetic rates $\left(A_{\max }\right)$ (Fig. 3a). This indicates that the removal of the competing vegetation increased leaf $\mathrm{C}$ assimilation during the first year after plantation although this gain was not allocated in the stem but in the establishment of larger root system. Higher $A_{\max }$ in the herbicide-treated poplar were directly related to area-based leaf nitrogen content (Fig. 4) which was significantly higher in the trees growing without the presence of competing vegetation (Fig. 3b). This clearly showed a damaging impact of competing vegetation on leaf photosynthetic functions (e.g. light harvesting and $\mathrm{CO}_{2}$ fixation) through a reduction of leaf $\mathrm{N}$ concentration $[13,21]$. Relative chlorophyll content correlated well with leaf nitrogen as noted 


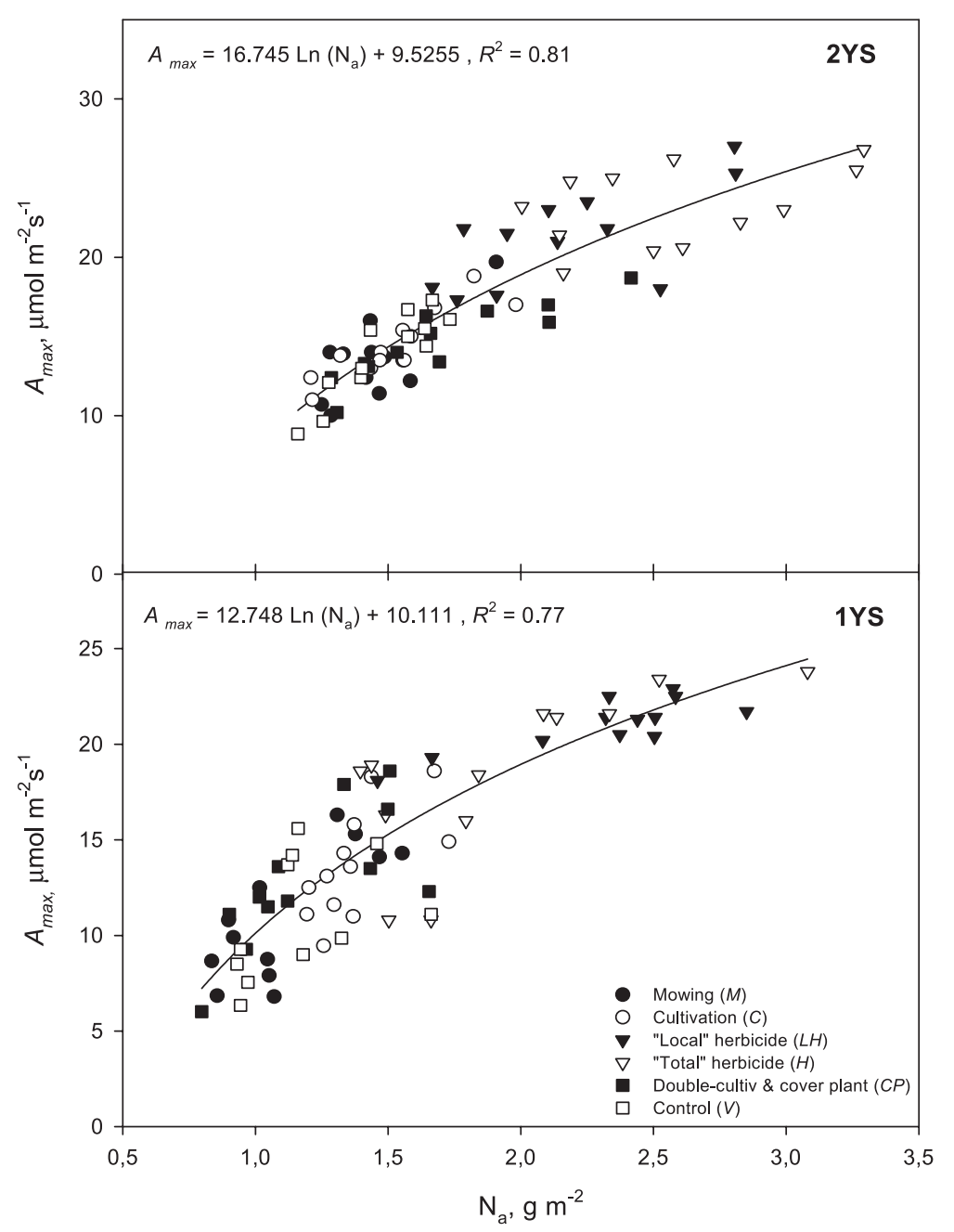

Figure 4. Relationship between maximum rate of photosynthesis and leaf nitrogen concentration (area basis) for the trees planted two years ago (2YS) and the same year of the study (1YS).

by Van den Berg and Perkins [48] and followed the same pattern than $\mathrm{N} \%$ and $\mathrm{N}_{a}$; being higher in the herbicide treatments (Fig. 3c). In agreement with Coleman et al. [11] we think that the measurements obtained with the SPAD meter can be a useful technique to rapid estimate leaf $\mathrm{N}$ concentration and $A_{\max }$ in poplar plantations.

Since our study area is characterized by frequent and abundant precipitation during the summer which maintains the soil well watered throughout the growing season, we believe that water competition by weeds played a minor role compared to nutrient competition (and particularly $\mathrm{N}$ ) in the establishment success and growth of hybrid poplars. That was confirmed by the high $C_{i} / C_{a}$ values that were found in the non-herbicide plants (ranging between 0.7 and 0.76 ) which were higher than the herbicide-treated plants and indicated that plants were not growing under water limiting conditions [54]. A similar response was obtained by Livingston et al. [32] for Picea glauca (Moench) Voss seedlings when growing with limited N supply but under well watered conditions. The high values of SWC we obtained in a measurement made between two rainfall events in the summer and the lack of differences among treatments supported that assumption. Critical competition from weeds for $\mathrm{N}$ on young forest plantations has often been reported $[27,45,55]$ and, in our sites, this may have been enhanced by high $\mathrm{C} / \mathrm{N}$ ratio (through plant residues) and nitrogen immobilization processes following logging [49].

Finally it is possible that the complete removal of the competitive vegetation following herbicide application increased soil temperature and thus improved the soil water and nutrient uptake capabilities of trees and, consequently, hybrid poplar growth $[8,19]$.

\subsection{Biomass allocation response of plants to belowground competition}

In the 1 year-old sites, plant allocation patterns were mainly explained by tree size. The first year after planting, hybrid poplar grew very little and thus initial size at planting and particularly stem length (since all plants at planting had comparable root biomass and were without any branch) account 
Table II. Summary of ANCOVA $P$-values $(* P<0.1$, ** $P<0.05$, *** $P<0.01)$ for relationships between allocation ratios and vegetation management treatment (Tr), plant height and the interaction of $\mathrm{Tr}$ and height for 1-year old (1YS) and the 2-year old (2YS) sites. Abbreviations: leaf weight ratio (LWR, $\mathrm{g} \mathrm{g}^{-1}$ ), stem weight ratio (SWR, $\mathrm{g} \mathrm{g}^{-1}$ ), branch weight ratio (BWR, $\mathrm{g} \mathrm{g}^{-1}$ ), root weight ratio (RWR, $\mathrm{g} \mathrm{g}^{-1}$ ) and fine-root leaf ratio (FRLR, $\mathrm{g} \mathrm{g}^{-1}$ ).

\begin{tabular}{lcccccccc}
\hline & \multicolumn{2}{c}{ Treatment } & & \multicolumn{2}{c}{ Height } & & \multicolumn{2}{c}{ Tr $\times$ Height } \\
\cline { 2 - 3 } Parameter & 1 YS & 2 YS & & 1YS & 2YS & & 1YS & 2YS \\
\hline LWR & 0.8995 & $0.0858 *$ & & 0.3523 & 0.2315 & & 0.7537 & 0.4289 \\
SWR & 0.2116 & 0.7408 & & $0.0016 * * *$ & 0.6159 & & 0.1750 & 0.7741 \\
BWR & 0.4180 & $0.0843 *$ & & $0.0026 * * *$ & $0.0438 * *$ & & 0.3663 & 0.4168 \\
RWR & 0.4933 & 0.4103 & & $0.0657 *$ & $0.0026 * * *$ & 0.4610 & 0.7277 \\
FRLR & $0.0586 *$ & 0.1143 & & 0.5013 & $0.0274 * *$ & & 0.2722 & 0.2259 \\
\hline
\end{tabular}

for most biomass allocation differences among plants. However plants in LH presented higher fine-root:leaf mass ratio than plants from $V$ or $C P$ treatments (Fig. 7). Since in the $1 Y S$ tall bare root plants were used to minimize deer damage, $\mathrm{LH}$ plants probably take advantage of the absence of competing roots in the soil space to develop their root system $[2,14]$ in order to equilibrate quickly the balance between the aerial and the belowground part of the trees and thus increase its establishment success [51]. Hence, we think that despite the lack of effect of any vegetation management treatment on the growth of recent established hybrid poplar plants, an efficient control of the belowground competition is needed because (1) it improves the nitrogen status of plants and its carbon assimilation capacity and (2) it favours the development of the plant root system (where the fixed $\mathrm{C}$ is preferentially allocated) and thus plant establishment.

2YS plants responded more markedly in terms of growth and biomass allocation than 1YS to the control of the competing vegetation. However, most variation in biomass allocation patterns between plants was associated to differences in plant size rather than to different competition scenarios (Tab. II) and thus they seemed to have an ontogenetic origin $[10,18]$. Belowground, we found a decrease of RWR in LH plants but this was a consequence of the accelerated development they experienced under favourable belowground growth conditions as reported by Cahill [7] and Coyle and Coleman [15]. A near significant effect $(P<0.10)$ of vegetation removal in LWF and BWR was nonetheless detected; probably indicating that biomass allocation is somehow sensitive to resource availability. However their effect is fairly small and strongly dependent on ontogeny $[18,25,31,35]$.

\subsection{Management consequences and conclusion}

We reported high increases in hybrid poplar growth, photosynthetic activities and modification in biomass allocation when plants were growing without competing vegetation at or around the tree base. This effect was mainly due to competition for nutrients, at least $\mathrm{N}$. The mechanical treatments (mowing and soil cultivation) which are at present used by

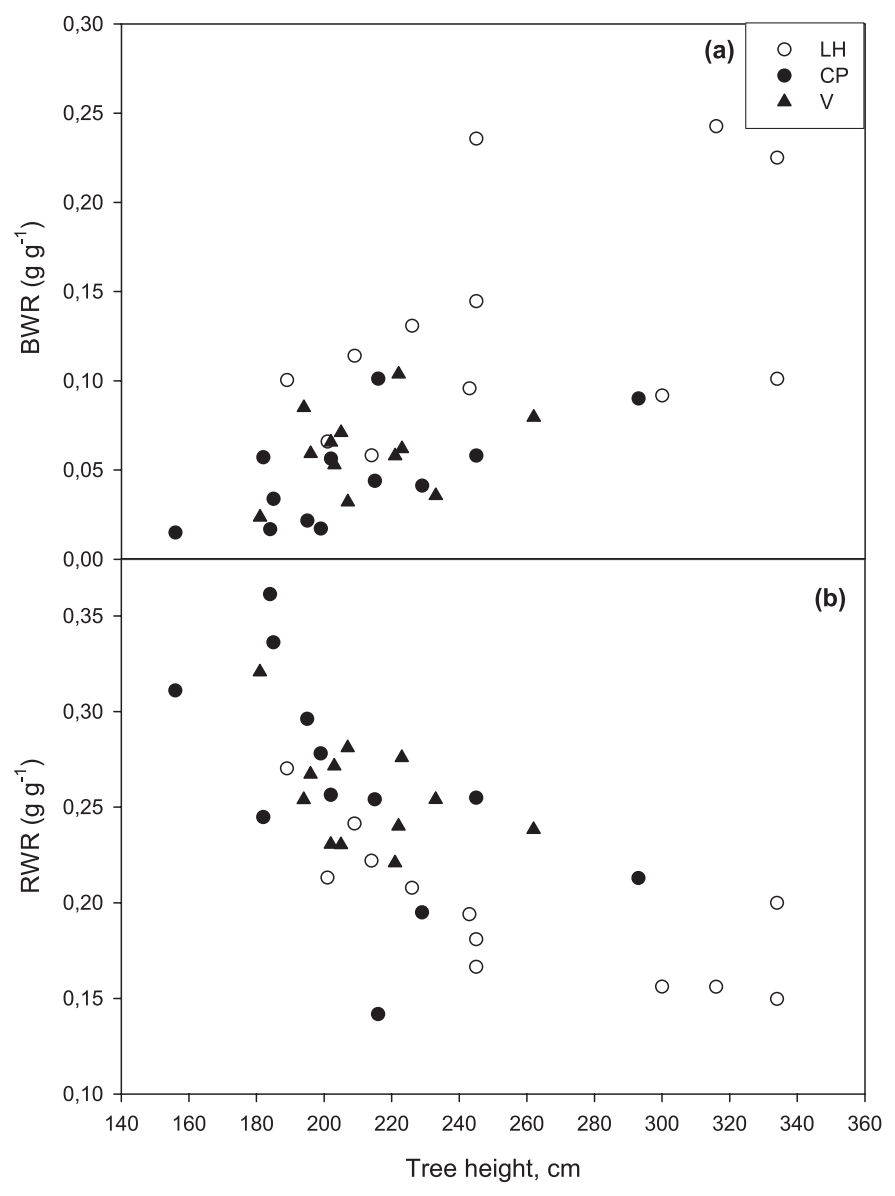

Figure 5. Variations in the (a) branch weight ratio (BWR, $\mathrm{g} \mathrm{g}^{-1}$ ) and (b) root weight ratio (RWR, $\mathrm{g} \mathrm{g}^{-1}$ ) versus tree height $(\mathrm{cm})$ in trees from the locally herbicide-treated plots $(L H, \circ)$, the mechanically double-cultivated plots $(C P, \bullet)$ and the control plots $(V, \boldsymbol{\Delta})$ of the 2-year old site (2YS). The number of sampled trees was 12 per treatment.

local forest industry showed low effectiveness in controlling competing vegetation both between rows and at the tree base and therefore they had almost no effect on improving growth, nutrient status and photosynthetic capacity of hybrid poplars during their establishment phase. The SPAD meter allow for a rapid estimation of leaf $\mathrm{N}$ and the photosynthetic capacity of trees and thus can be easily used by forest managers to detect nitrogen deficiencies in young plantations.

Overall, our results indicate the need for a good control of competing vegetation at the base of the tree from the first year after planting. Further studies are required to determine (1) whether and when the control of the vegetation between rows is necessary later on, (2) if such early control of competing vegetation at the base of the tree will have long-term positive effects in term of growth, (3) if such early vegetation control makes economical sense in the long-term and (4) if fertilisation could be used early on instead of competition control to maximize growth. 


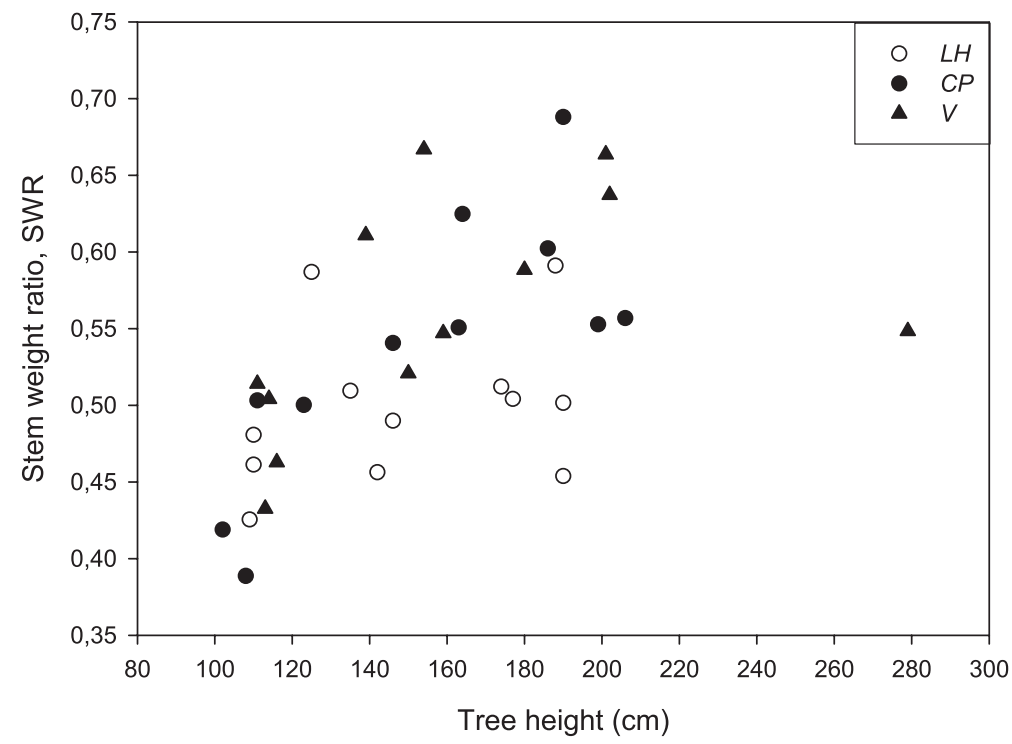

Figure 6. Relationship between the stem weight ratio $\left(\mathrm{SWR}, \mathrm{g} \mathrm{g}^{-1}\right)$ and tree height $(\mathrm{cm})$ in trees from the local herbicide-treated plots $(L H, \circ)$, the mechanically double-cultivated plots $(C P, \bullet)$ and the control plots $(V, \mathbf{\Delta})$ of the recently established plantations $(1 Y S)$. The number of sampled trees was 12 per treatment.

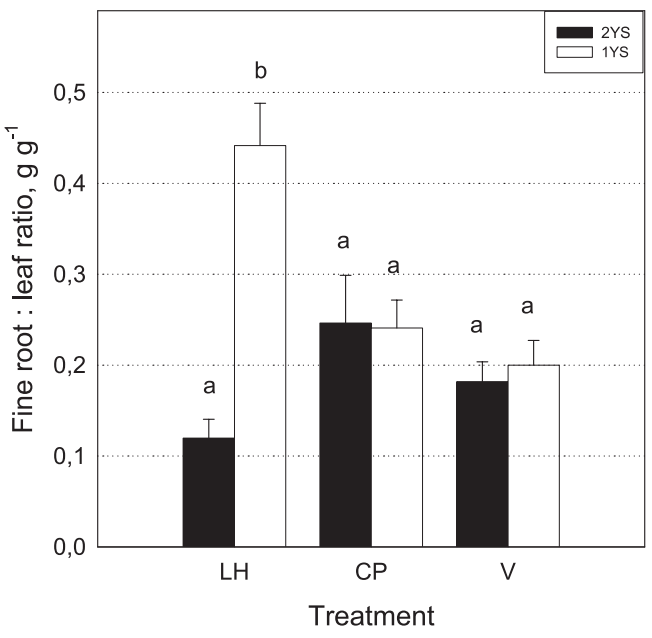

Figure 7. Variation among vegetation control treatments in the fineroot leaf biomass ratio (FRLR, $\mathrm{g} \mathrm{g}^{-1}$ ) of trees for the 2-year old plantation (2YS, black columns, $n=12$ ) and the recently established plantations (1YS, white columns, $n=12$ ). " $L H$ " indicates localherbicide treatment, " $C P$ " mechanically double-cultivated treatment and $\mathrm{V}$ the control (non vegetation control) treatment. Mean and standard error are represented. Different letters in the graph indicate (for each plantation year) statistically significant differences (Bonferroni $t$-test, $95 \%$ confidence interval).

Acknowledgements: We thank Domtar Inc. for logistic support and permission to work in their plantations. We are very grateful to A. Poitras, L. Mateu, S. Domenicano and D. Senecal for their valuable help in the field and L. Ruddick for English revision. This research was supported primarily by NSERC and Domtar Inc., with additional inputs from the Ligniculture Quebec Network (Réseau Ligniculture Québec) and the Quebec Ministry of Natural Resources. L. Coll was supported during 2006 by a "Juan de la Cierva" contract from the Spanish ministry of Education and Science.

\section{REFERENCES}

[1] Adams J.C., Mulching improves early growth of four oak species in plantation establishment, South. J. Appl. For. 21 (1997) 44-46.

[2] Balandier P., De Montard F.X., Curt T., Root competition for water between trees and grass in a silvopastoral plot of ten-year-old Prunus avium, in: Batish D.R., Kohli R.K., Jose S., Singh H.P. (Eds.), Ecological basis of agroforestry, CRC Press, USA, 2007 (in press).

[3] Balandier P., Collet C., Miller J.H., Reynolds P.E., Zedaker S.M., Designing forest vegetation management strategies based on the mechanisms and dynamics of crop tree competition by neighboring vegetation, Forestry 79 (2006) 4-27.

[4] Boulet-Gercourt B. (coord.), Élaboration de systèmes de boisements forestiers sur déprises agricoles mettant en œuvre des techniques d'entretien du sol alternatives aux herbicides chimiques et d'éducation des arbres objectifs par un accompagnement ligneux, ACTA, IDF, Rennes, France, Rapport n 96/02, 1999.

[5] Bowersox T.W., Stover L.R., Strauss C.H., Blankerhorn P.R., Advantages of an effective weed control program for Populus hybrids, Tree Plant. Notes 43 (1992) 81-86.

[6] Buhler D.D., Netzer D.A., Riemenschneider D.E., Hartzler R.G., Weed management in short rotation poplar and herbaceous perennial crops grown for biofuel production, Biomass Bioenergy 14 (1998) 385-394.

[7] Cahill J.F. Jr., Lack of relationship between below-ground competition and allocation to roots in 10 grassland species, J. Ecol. 91 (2003) 532-540.

[8] Cogliastro A., Gagnon D., Bouchard A., Effet des sites et des traitements sylvicoles sur la croissance, l'allocation en biomasse et 
l'utilisation de l'azote de semis de quatre espèces feuillus en plantations dans le sud-ouest du Québec, Can. J. For. Res. 23 (1993) 199-209.

[9] Cole E., Youngblood A., Newton M., Effects of competing vegetation on juvenile white spruce (Picea glauca (Moench) Voss) growth in Alaska, Ann. For. Sci. 60 (2003) 573-583.

[10] Coleman J.S., McConnaughay K.D.M., Ackerly D.D., Interpreting phenotypic variation in plants, Trends Ecol. Evol. 9 (1994) 187-191.

[11] Coleman M.D., Dickson R.E., Isebrands J.G., Growth and physiology of aspen supplied with different fertilizer addition rates, Physiol. Plant. 103 (1998) 513-526.

[12] Coleman M., Friend A.L., Kern C.C., Carbon allocation and nitrogen acquisition in a developing Populus deltoides plantation, Tree Physiol. 24 (2004) 1347-1357.

[13] Coll L., Balandier P., Picon-Cochard C., Morphological and physiological response of beech (Fagus sylvatica) seedlings to grassinduced belowground competition, Tree Physiol. 24 (2004) 45-54.

[14] Collet C., Löf M., Pagès L., Root system development of oak seedlings analysed using an architectural model. Effects of competition with grass, Plant Soil 279 (2006) 367-383.

[15] Coyle D.R., Coleman M.D., Forest production responses to irrigation and fertilization are not explained by shifts in allocation, For. Ecol. Manage. 208 (2005) 137-152.

[16] Curt T., Coll L., Prévosto B., Balandier P., Kunstler G., Plasticity in growth, biomass allocation and root morphology in beech seedlings as induced by irradiance and herbaceous competition, Ann. For. Sci. 62 (2005) 51-60.

[17] Davies R.J., Trees and weeds. Weed control for successful tree establishment, in: Forestry Commission Handbook, HMSO Publications, London, 1987, pp. 2-36.

[18] Delagrange S., Messier C., Lechowicz M.J., Dizengremel P., Physiological, morphological and allocational plasticity in understory deciduous trees: importance of individual size and light availability, Tree Physiol. 24 (2004) 775-784.

[19] Dupuis M., Plantation de feuillus de grande valeur en friche herbacée : impacts éco-physio-morphologiques de diverses méthodes de repression de la végétation, M. Sc. thesis, Université Laval, Canada, 1997.

[20] Environnement Canada, Centre de ressources en impacts et adaptation au climat et à ses changements, Montréal, http://www.criacc.qc.ca/index.html, 2004

[21] Evans J.R., Photosynthesis and nitrogen relationships in leaves of C3 plants, Oecologia 78 (1989) 9-19.

[22] Frochot H., Picard J.F., Dreyfus P., La végétation herbacée obstacle aux plantations, Rev. For. Fr. 38 (1986) 271-279.

[23] Frochot H., Armand G., Gama A., Nouveau M., Wehrlen L., La gestion de la végétation accompagnatrice : état et perspective, Rev. For. Fr. 44 (2002) 505-520.

[24] Frochot H., Collet C., Balandier P., Wagner R., Technical, environmental and economic challenges of forest vegetation management - 4th International Conference on Forest Vegetation Management IFVMC4 - 17-21 June 2002, Nancy, France - Foreword, Ann. For. Sci. 60 (2003) 558-558.

[25] Gedroc J.J., McConnaughay K.D.M., Coleman J.S., Plasticity in root/shoot partitioning: optimal, ontogenetic, or both? Funct. Ecol. 10 (1996) 44-50.
[26] Green D.S., Kruger E.L., Stanosz G.R., Effects of polyethylene mulch in a short-rotation, poplar plantation vary with weed-control strategies, site quality and clone, For. Ecol. Manage. 173 (2003) 251-260.

[27] Hangs R.D., Greer K.J., Sulewski A., The effect of interspecific competition on conifer-seedling growth and nitrogen availability measured using ion-exchange membranes, Can. J. For. Res. 34 (2004) $754-761$.

[28] Hansen E.A., Netzer D.A., Weed control using herbicides in shortrotation intensively cultured poplar plantations, U.S. Dept. Agr., For. Serv. North Central For. Exp. Station, Res. Pap. NC-260, 1985.

[29] Hansen E.A., Netzer D.A., Tolsted D.N., Guidelines for establishing poplar plantations in the North-Central USA, U.S. Dept. Agr., For. Serv. North Central For. Exp. Station, Res. Pap. NC-363, 1993.

[30] Haywood J.D., Mulch and hexazinone herbicide shorten the time longleaf pine seedlings are in the grass stage and increase height growth, New For. 19 (2000) 279-290.

[31] King J.S., Albaugh T.J., Allen H.L., Kress L.W., Stand-level allometry in Pinus taeda as affected by irrigation and fertilization, Tree Physiol. 19 (1999) 769-778.

[32] Livingston N.J., Guy R.D., Sun Z.J., Ethier G.J., The effects of nitrogen stress on the stable carbon isotope composition, productivity and water use efficiency of white spruce (Picea glauca (Moench) Voss) seedlings, Plant Cell Environ. 22 (1999) 281-289.

[33] Löf M., Welander N.T., Influence of herbaceous competitors on early growth in direct seeded Fagus sylvatica L. and Quercus robur L., Ann. For. Sci. 61 (2004) 781-788.

[34] Mc Carthy N., Mc Carthy C., Herbicides and forest vegetation management: A review of possible alternatives, Irish Forestry 62 (2005) $44-57$.

[35] McConnaughay K.D.M., Coleman J.S., Biomass allocation in plants: ontogeny or optimality? A test along three resource gradients, Ecology 80 (1999) 2581-2593.

[36] McDonald P.M., Helgerson O.T., Mulches aid in regenerating California and Oregon forests: past, present and future, U.S. Dept. Agric. For., Berkeley, CA, Gen. Tech. Rep. PSW-123, 1990.

[37] Messier C., Bigué F., Using fast-growing plantations to promote forest ecosystem protection in Canada, in IUFRO meeting on Management of Fast Growing Plantations, Izmit (Turkey), 11-13 September 2002, 2002, 11 p.

[38] Provendier D., Balandier P., Contrôler la végétation en plantation forestière : premiers résultats sur les modifications microenvironnementales engendrées par l'utilisation de plantes de couverture, Ingénieries 40 (2004) 61-72.

[39] Robitaille D., Protection des plantations de feuillus contre la végétation concurrente dans les friches herbacées : plantation de Beaumont - Résultats de sept ans, MRNFP, Dir. Rech. For., Mémoire de recherche forestière $\mathrm{n}^{\circ} 142,2003$.

[40] Rose R., Ketchum J.S., Hanson D.E., Three-year survival and growth of Douglas-fir seedlings Ander various vegetation-free regimes, For. Sci. 45 (1999) 117-126.

[41] Rose R., Rosner L., Eight-year response of Douglas-fir seedlings to area of weed control and herbaceous versus woody weed control, Ann. For. Sci. 62 (2005) 481-492.

[42] Schütz J-P., Opportunistic methods of controlling vegetation, inspired by natural plant succession dynamics with special reference to natural outmixing tendencies in a gap regeneration, Ann. For. Sci. 61 (2004) 149-156. 
[43] South D.B., Top-pruning bareroot hardwoods: a review of the literature, Tree Plant. Notes 47 (1996) 34-40.

[44] Stanturf J.A., van Oosten C., Netzer D.A., Coleman M.D., Portwood C.J., Ecology and silviculture of poplar plantations, in: Dickmann D.I., Isebrands J.G., Eckenwalder J.E., Richardson J. (Eds.), Poplar culture in North America, NRC Research Press, Ottawa, 2001, pp. 153-206.

[45] Staples T.E., Van Rees K.C.J., Van Kessel C., Nitrogen competition using ${ }^{15} \mathrm{~N}$ between early successional plants and planted white spruce seedlings, Can. J. For. Res. 29 (1999) 1282-1289.

[46] Thomas K.D., Reid W.J., Comeau P.G., Vegetation management using polyethylene mulch mats and glyphosate herbicide in a coastal British Columbia hybrid poplar plantation: four-year growth response, W. J. Appl. For. 16 (2001) 26-30.

[47] Thompson D.G., Pitt D.G., A review of Canadian forest vegetation management research and practice, Ann. For. Sci. 60 (2003) $559-572$.

[48] Van den Berg A.K., Perkins T.D., Evaluation of a portable chlorophyll meter to estimate chlorophyll and nitrogen contents in sugar maple (Acer saccharum Marsh.) leaves, For. Ecol. Manage. 200 (2004) 113-117.
[49] Vitousek P.M., Gosz J.R., Grier C.C., Melillo J.M., Reiners W.A., A comparative analysis of potential nitrification and nitrate mobility in forest ecosystems, Ecol. Monogr. 52 (1982) 155-177.

[50] Von Althen F.W., Site preparation and post-planting weed control in hardwood afforestation: White ash, walnut, basswood, silver maple, hybrid poplar, Can. For. Serv. Saulte Ste. Marie, Rep. No. O-X-235, 1981.

[51] Watson W.T., Influence of tree size on transplant establishment and growth, Horttechnology 15 (2005) 118-122.

[52] Willoughby I., McDonald H.G., Vegetation management in farm forestry: a comparison of alternative methods of inter-row management, Forestry 72 (1999) 109-121.

[53] Wilson S.D., Tilman D., Competitive responses of eight old-field plants species in four environments, Ecology 76 (1995) 1169-1180.

[54] Wong S.C., Cowan I.R., Farquhar G.D., Stomatal conductance correlates with photosynthetic capacity, Nature 282 (1979) 424-426.

[55] Woods P.V., Nambiar E.K.S., Smethurst P.J., Effect of annual weeds on water and nitrogen availability to Pinus radiata trees in young plantation, For. Ecol. Manage. 48 (1992) 145-163. 